\title{
Sanatta Gerçeğin Sinemasal Olanaklılığı ya da Olanaksızlığı: Otto e Mezzo (1963), Andrei Rublev (1966) Synecdoche, New York (2008)
}

\author{
M. Ceren Arslan *
}

Özet

Otto e Mezzo, Andrei Rublev, Synecdoche, New York filmleri ilk bakışta çok farkli filmler gibi görünseler de üç filmi birbirine bağlayan önemli bir ortak nokta vardır: Yaratma sürecindeki sanatçının krizinin, gerçeğin sanatsal yaratımina dair estetik bir çıkmazdan kaynaklanması. Üç film de yönetmenleri olan Federico Fellini, Andrei Tarkovski ve Charlie Kaufman'ın gerçeğe yaklaşımlarının yoğun öznelliğini taşır. Çalışma kapsamında, estetik teorisini çıkış noktası olarak alnacak Oscar Wilde, sanatın yalnızca kendini ifade ettiğini söylemiş ve sanatın hayatı taklit etmesinden daha çok hayatın sanatı taklit ettiğini iddia etmiştir. Sinema da tarih sahnesine ilk çıktığ andan itibaren gerçekliğe dair başl başına bir tartışma alanı oluşturmuştur. Ele alnacak üç film, gerçekliğe karşı farklı yaklaşımları ortaya koyar. Çalışmanın kapsamı sinemayı bir sanat disiplini olarak kabul ettikten sonra Oscar Wilde'ın görüşlerinden yola çıkarak, yaratma krizindeki sanatçı karakteri ve yaratıcısı olan yönetmenlerinin yaklaşımlarım filmleri üzerinden incelemektir. Bunu yaparken, biçim ve içerik düzeyinde, sanatta gerçeğin sinemasal yeniden yaratımının olanaklılığın ya da olanaksızh̆̆ı̆ı, sanatta sinemasal anlatım olarak tartışmaktır. Otto e Mezzo ve Andrei Rublev filmlerinde sanatçının, yaratma krizini aşması, sanatın dışsal değil içsel bir özü olduğunu kabul etmesi ile mümkün olur. Synecdoche, New York'ta ise bunu kabul edemeyen sanatçı kendi eserinin içinde kaybolur fakat yaratıcısı olan yönetmeni Kaufman, eseri yaratarak krizi aşar ve gerçeğin, gerçek-ötesi yorumunu sunan bir film çeker. Oscar Wilde'tn estetik teorilerinden de yola çıkarak, üç filmin karşılaştırılmasından varılan sonuca göre, sanat eseri kendi gerçekliğini oluştururken dışsal gerçekten bağımsızdır ve bunu yaparken de kendi hakikatini yaratır.

Anahtar Kelimeler: Otto e Mezzo, Andrei Rublev, Synecdoche, New York, gerçeklik, temsil I

*ORCID: 0000-0001-7981-096x

E-Mail: mceren.1408@gmail.com

DOI: 10.31122 / sinefilozofi.673205

Geliş Tarihi - Recieved: 15.01.2020

Kabul Tarihi - Accepted: 10.05.2020 


\title{
Cinematic Possibility or Impossibility of Truth in Art: Otto e Mezzo (1963), Andrei Rublev (1966) Synecdoche, New York (2008)
}

\author{
M. Ceren Arslan*
}

\begin{abstract}
Although the films Otto e Mezzo, Andrei Rublev andSynecdoche, New York appear to be very different at first glance, there is one important common point that connects the three films: This crisis of the artist in the process of creation stems from an aesthetic impasse about the artistic creation of reality. All three films feature intense subjectivity of their directors Federico Fellini, Andrei Tarkovski and Charlie Kaufman's approach to reality. Oscar Wilde, whose aesthetic theory we will take as the starting point in the study, said that art expresses only itself and claims that life imitates art rather than art imitates life. Cinema also has been an area of debate about reality from the moment it first appeared on the stage of history. The three films to be discussed present different approaches to reality. The scope of the study is to analyze the character of the artist in the crisis of creation and the approaches of the directors who are the creators, based on the views of Oscar Wilde and through the movies, after accepting cinema as an art discipline. In doing so, the aim is to discuss the possibility or impossibility of the cinematic re-creation of reality in art, in terms of form and content, within the light of cinematic expression in art. Yet another aim is to discuss the possibility or impossibility of cinematic re-creation of art as cinematic narration at the level of form and content. In the movies Otto $e$ Mezzo and Andrei Rublev, it is possible for the artist to overcome the crisis of creation by accepting that art has an inner essence, not an external one. In Synecdoche, New York, the artist disappears into his own work, but his creator, director Kaufman, overcomes the crisis by creating the work and makes a film that offers a fictitious interpretation of reality. Based also on the aesthetic theories of Oscar Wilde, the comparison of the three films concludes that the work of art is independent from external reality while creating its own truth and makes its own actuality in doing so.
\end{abstract}

Keywords: Otto e Mezzo, Andrei Rublev, Synecdoche, New York, reality, representation

*ORCID: 0000-0001-7981-096x

E-Mail: mceren.1408@gmail.com

DOI: 10.31122/sinefilozofi.673205

Received - Geliş Tarihi: 15.01.2020

Accepted - Kabul Tarihi: 10.05.2020 


\section{Giriş}

Otto e Mezzo (Sekiz Buçuk, Federico Fellini, 1963), Andrei Rublev (Andrei Tarkovski, 1966) ve Synecdoche, New York (New York Yanılsamaları, Charlie Kaufman, 2008) filmlerinde gerçekliğin bir sanatsal tercih olarak temsil edilme biçimi ve yaratıcısıyla kurduğu ilişkinin, yaratma krizindeki sanatçıdan yola çıkarak incelemesi amaçlanmaktadır. Çalışmada seçilen filmlerden yola çıkarak sanatın, sanatçısıyla kurduğu ilişki, biçimsel düzeyde; sinematografik araçlarla temsili ve içerik düzeyinde; sanatçı karakteri aracılığıyla gerçekle kurduğu farklı yaklaşımlar karşılaştırılacaktır.

Üç filmin ortak noktası, bir krizin içindeki sanatçının yaratma krizinin kaynağının estetik-etik bir çıkmazdan kaynaklanmasıdır; bu çıkmaz gerçeğin sanatsal temsilinin olanaksızlığıdır. Otto e Mezzo filminin ana karakteri yönetmen Guido, dürüst bir film yapma isteğiyle yola çıkmış ama hiçbir şey söyleyemez hale gelmiştir. Andrei Rublev' de, 14. yüzyılda yaşamış ünlü ikon ressamı olan Andrei, ikonlarında canlandıracağı ilahi bir yüz arar ama bu yüzü bulamadığı için hem resmi bırakır hem de sessizlik yemini eder. Günümüzde geçen Synecdoche, New York'ta ise oyun yönetmeni Caden, doğru, gerçek ve dürüst bir tiyatro oyunu için hazırlanmaya başlar ama yıllar süren yaratım sürecinin sonucunda kendi yarattığı gerçekliğin içinde kaybolur. Bu bağlamda gerçeğin sanatsal olarak temsil edilmesi, yeniden üretilmesi, yaratılması, canlandırılması, ya da gerçeğin herhangi bir şekilde sanatsal bir yöntemle imlenmesinin olanağı ya da olanaksızlı̆̆ sorgulanacaktır.

Üç filmin gerçekliğe yaklaşımını sinema alanında çok tercih edilmeyen bir isimle bir araya getirmeyi umuyoruz. Çalışmanın görüşleri doğrultusunda sanatın gerçekle kurduğu ilişkiyi en 'güzel' biçimde ortaya koyan ve eserleriyle de bunu dile getiren, Estetizmin önde gelen temsilcisi, eleştirmen, oyun yazarı, romanc1, kısa öykücü, şair, güzelliğe âşık dandy Oscar Wilde'ın estetik teorileri. Wilde'ın Yalanın Gözden Düşüşü: Bir Gözlem yazısına göre incelediğimizde üç filmin beklenmedik bir ortaklığa kavuştuğunu düşünüyoruz.

\section{Sanatın Gerçeklikle Muharebesi: Estetik ve Etik}

Bizim, ya da herhangi başka birinin sanatın net ve kesin bir tanımını yapmasının imkânsız olduğu, sanatın bu tanımlanabilir sınırlamaların ötesinde bir varlığı olduğu ön kabulüyle, sanata dair, çalışmamız kapsamında nasıl bir yaklaşım getirileceğinden kısaca bahsedersek:

\footnotetext{
"Sanat etkinliği en geniş anlamıyla benliğin kişiliğe dönüştürülmesi eylemi olup, dışımızdaki dünyalara duyulan ilgi ve bilinmeyenlerin çekiciliği de bu eylemimizi besleyen ana damarlardır. Varolanla varolmayan arasinda bir yerlerde bulunan sanatsal süreç, bu iki alan bir araya getirmeye çalışır. (...) sanat, insanın gerçekliği aşması ya da kendine özgü başka bir gerçeklik yaratmasıdır. Düşle gerçek arasında kurulan bir köprü olarak sanatsal etkinlik, ussal ile usdışı, düşlem ile gerçek, imgeler ile nesneler arasinda bir bă̆ kurma eylemidir" (Bozkurt, 1995: 9-10).
}

Alıntıda da öne çıktığı gibi sanatın temel çatışması, doğa-ötesi bir gerçek yaratması olarak, gerçekle giriştiği çatışmadır. Bir anlamda sanatsal biçimleri, yöntemleri, stilleri belirleyen de bu çatışmadan, çarpışmadan ya da savaştan çıkan sonuç ya zafer ya da yenilgidir. 
Sanat yalnızca sanat eseri yoluyla anlaşılabilir: Heidegger ise sanatın kökenini açıklarken, sanat eseriyle sarmal bir ilişki kurarak, "Sanat eserinin kökeni sanattır. Peki, sanat nedir? Sanat, gerçek sanat eserindedir. Bu yüzden eserin gerçekliğini arıoruz" (Heidegger, 2011: 35) der ve sanatı hakikate bağlar: "Sanat hakikatin işe koyulmasıdır. (...) Sanat tarihseldir ve tarihsel olarak eserdeki hakikatin yaratıcı korunumudur. (...) Sanat, hakikati ortaya çıkarır. Sanat kurucu koruma olarak, eserde var-olan hakikati çıkarır (Heidegger, 2011: 73)."

Sanatın, sanatta temsilin ya da mimetik sanatların gerçekle kurduğu bu ilişki sanata dair tartışmalarda hep başat bir konumda olmuştur. Sanat tarihi bir anlamda temsillerin değişiminin, evriminin tarihidir. Belirlediği ilk estetik tartışmalarda, sanatçının toplumdaki yerini sorgulayan Platon, sanatçının taklitçi olarak gerçeği yansıtamayacağını o yüzden bu beyhude çabanın topluma zarar olarak geri döneceğine inanmış, ama onun görüşleri NeoPlaton'cular tarafından başka bir alana kanalize edilerek, idealin gerçekliğinin arayışına dönüşmüştür. Modernizm ile beraber Empresyonistler ise eserin kendisinin vurgulayıp öz göndergesel yapitlarla gerçekliğin değil sanat eserinin gerçekliğini vurgulamaya başlamışlardır.

Ama sanatın etik ile ilişkisi, gerçekliğin sanatta temsilinin etik tartışması hiç son bulmamıştır. Estetik, bir disiplin olarak ilk ortaya çıktığında neredeyse etik'le eşdeğer olarak ele alınırken Immanuel Kant, onu etik'ten ayırıp ayrı bir alan olarak tanımlayan ilk filozof olmasına rağmen, üçüncü ve son krtiği olan Yargıgücünün Kritiği'nde "teleoloji, ahlakî vazifelerimizle ahenk içinde bir doğa vizyonu oluşturmak suretiyle, teorik doğa bilimlerini ahlakî amaçlar sistemine nihâ̂ olarak bağlar. Böylelikle teorik akıl ile pratik akıl, özgürlük ile doğa arasındaki uçurumu kapatmış olur" (Wood, 2009: 93-194) ve "yüce" nin tanımının yine moral değerlerle tanımlayarak etik'le estetik bir ilişki kurmuş olur.

Öyleyse, üç filmde de gerçekliğin yeniden üretiminin etik sorumluluğunun yarattığ1 estetik krizin dayandığı şey gerçeğin ele geçirilemezliğidir. Bu noktada, öyleyse gerçek nedir, diye kendimizi yanıtlanması olanaksız olan başka bir sorunun eşiğinde buluruz. Gerçeklik, tıpkı sanat gibi, fenemolojik, estetik, ontolojik... yaklaşımlarla ele alınabilir. Bu çalışmanın kapsamında, gerçekliğin ele alınma biçimlerine dair ihtimallerden sadece birini göz önünde bulundurulacaktır: 'Gerçeklik ilkesi' ya da gerçeklik, modern toplumlara ait bir duygudan, bir tür metafizik, neredeyse zihinsel bir süreçten ibarettir (Adanır, 2008: 75).

Oscar Wilde ise Modernist sanat içinde geliştirdiği doğal gerçekliğe dair ters yüz edilmiş bakışında, bir gerçeklik kaynağı olarak doğanın insan beyninde hayat bulduğunu söyler:

"Doğa nedir aslında? Doğa bizim beynimizde hayat bulur. Bizi doğurmuş olan bir tabiat anadan bahsedemeyiz, çünkü tabiatı yaratan biziz. Doğanın bize hayat verdiği söyleniyor; boş bir laftır bu. Şeyler, biz onlarn gördüğümüz için orada dururlar; ne gördüğümüz, o gördüğ̈̈müz şeyi nasıl gördüğümüz, bizi etkilemiş olan sanatlara bağ̆lıır yalnızca" (Wilde, 2008: 192).

İlk bakışta provoke edici olmak için söylenmiş gibi duran bu cümleler, onun ifadesiyle "metafizik ya da biçimsel bir bakış açısıyla bakılan" (Wilde, 2008: 192) Wilde'ın estetik teorisiyle beraber düşünüldüğünde anlam kazanır. Yaşamını da tamamlanmamış külliyatının bir 
fragmanı olarak gören Wilde, estetik kuramlarında temel olarak John Ruskin ve Walter Pater'den etkilenerek kurar ve sanata fenomolojik bir boyutu olduğu kadar etik bir mesele olarak bakar. Ona göre toplumla ilişkili olarak birey, kendini gerçekleştirmek için sanat'a ihtiyaç duyar1. Wilde, aynı zamanda bütün eserlerini, sanat teorilerini kurgusal evrenine yansitarak kurmuş bir sanatçıdır. Dorian Gray'in Portresi, Bay W.H.'nin Portresi, Ciddi Olmanın Önemi gibi kurgusal eserlerinde karakterler belli bir kurgu-gerçek çatışmasının içinde kalırken, özellikle De Profundis gibi kurgusal olmayan çalışmalarında da estetiği, etik hatta ruhani bir mesele olarak ele almıştır.

Yalanın Gözden Düşüşü: Bir Gözlem başlıklı yazısında Wilde, meşhur, sanatın hayatı değil, hayatın sanatı taklit ettiği fikrini açıklar:

"Sanat, soyut süslemelerle, gerçek dı̧̧ı, var olmayan şeylere yönelik, tamamen hayal gücünün ürünü ve hoş işlerle başlar. Bu ilk evredir. Sonra, hayat, gözlerinin önünde vuku bulan bu mucizeden büyülenerek, kendisi de bu güzel, cazip dünyaya kabul edilmeyi ister. Sanat, hayatı ham maddesi olarak alır, onu yeniden yaratıp yeniden biçimlendirir; bu esnada, gerçeklere karşı tamamen kayıtsızdır. Sanat, icat eder, hayal eder, düş kurar ve öylesine güzel bir üslupla, öylesine süslü bir biçimde konuşur ki, gerçek bu engelleri aşıp da onun yanına dahi yaklaşamaz" (Wilde, 2008: 177).

Diyalog şeklinde yazdığı yazısında, "O zaman sen, bana, doğanın manzara resimlerini taklit ettiğini, her türlü efekti ressamdan aldığını mı söylüyorsun?" (Wilde, 2008: 192) sorusunu, empresyonist ressamların kahverengi sisi tablolarına eklemeden Londra'nın ikliminin sisli olmadığını iddia ederek yanıtlar² ve kendisine gelen itirazlar için hayatın sanatı taklit ettiği örnekleri vererek sürdürür (Wilde, 2008: 191).

$\mathrm{Bu}$ bağlamda üç filmin gerçekle (sanatsal gerçeğin yaratıcısı olan sanatçısı aracılığıyla) kurduğu ilişki incelenmeden önce kısaca, bir sanat dalı -belki de yaşayan sanatların en büyüğü olarak gördüğümüz sinemanın gerçekle kurduğu ilişkinin gelişimine bakacağız.

\section{Sanatın Tekniğin Olanaklarıyla Yeniden Üretilebildiği Çağda Gerçeğin Yeniden Üretimi?}

Rudolf Arnheim, 1933 yılında yazdığı Film'den Uyarlanmış Seçmeler makalesini, 1957 yılında kişisel bir notla Sanat Olarak Sinema kitabının Amerika baskısında yeniden yayınlar. Arnheim, sinemanın yeni doğduğu yıllar sayılabilecek dönemlerde, sinemanın bir sanat olamayacağı, çünkü gerçeği olduğu gibi taklit ettiği görüşlerine yanıt olarak yazdığ1 makalesinin aradan geçen y1llara rağmen güncelliğini koruduğunu düşünür. Makalesinde,

\footnotetext{
${ }^{1}$ Wilde'ın estetik teorilerinin bir özeti için bkz: “Oscar Wilde” Elizabeth Hollander, Sanatçı: Eleştirmen, Yalancı, Katil kitabı içindeki sunuş.

2"Öyle diyorum, evet. Sokaklarımızda gezinen, gaz lambalarıın ışıklarını karartan, evleri devasa gölgelere dönüştüren o harikulade kahverengi sisler, şayet empresyonist ressamların tablolarından gelmiyorsa, nereden geliyor, doğrusu çok merak ediyorum. Son on yılda Londra'nın ikliminde meydana gelen olağanüstü değişimin arkasında bir sanat akımı bulunmaktadır. (...) insanların, sisi görebilmelerinin nedeni, sisin varlığı değildir; şairlerle ressamlar kendilerine onun esrarengiz güzelliğini öğrettiği için görüyorlar sisi. Londra'nın üstüne yüzyıllardır sisin çöktüğü söylenir. Ama kimse görmemiştir bu bahsedilen sisleri; kimse görmediği için de, onlar hakkında hiçbir şey bilmiyoruz. Sanat onları keşfedene kadar, sis var olmamıştır" (Wilde, 2008: 192). Bu konuyla ilgili olarak çok farklı bir bağlamda olsa da Wilde'ın yazısından yıllar sonra yayınlanan John Berger'in "Görme Biçimleri"yle bir ortaklık kurulabileceğini, sanatın gerçekle kurduğu ilişkide, özellikle reklamcılık, ya da kadın bedenine dair görsel bir beklentinin oluşması konularında dolaylı bir benzerlikten söz edilebileceğini düşünüyoruz.
} 
materyalin donanımlarıyla elde edilen biçimlendirmeden yola çıktığı, "materialtheorie" ismini verdiği kuram1, Marshall McLuhan'ın ünlü "the medium is the message (ortam mesajdır)" ifadesiyle benzerlik taşır ve sinemanın bir sanat olmasının materyalin eksiklerinin sebep olduğu yanılsama sayesinde mümkün olduğunu ifade eder:

"Bir olayın yalnızca esasları gösterildiğinden yanılsama oluşur. Ekrandaki insanlar, insan gibi davranı insanca olaylar yaşadıklarından, ne onlar elle tutulur canlı varlıklar olarak karşımızda görmemiz ne de gerçek uzamda bulunduklarım görmemiz gerekli değildir; onlar olduklarn gibi yeterince gerçektirler. Bu nedenle nesneleri ve olaylar hem canl hem de hayali, hem gerçek nesneler hem de ekrandaki basit ışı örnekleri olarak algılarız. Sinemanın sanat olmasını olanaklı kılan da bu gerçektir" (Arnheim, 2002: 32).

Arnheim'a göre, yönetmen, görüntülemek istediği belirli bir sahne seçer, bu sahne içindeki nesneleri dışarıda bırakabilir, gizleyebilir, dikkat çekici yapabilir... Kısaca filmin teknik olanaklarını kullanarak gerçeği istediği gibi sunabilir ama bunu yaparken "her şeye rağmen gerçeklikle çatışmayabilir" ve dünyayı yalnızca nesnel olarak görüldüğü gibi değil, ayrıca öznel olarak da gösterirken "yeni gerçeklikler yaratır" (Arnheim, 2002: 46).

Yine sinemanın hızla geliştiği dönemlerde, Sovyet Montaj Sineması'nın önde gelen yönetmenlerinden ve aynı zamanda film kuramcısı olan Pudovkin, filmsel gerçekliği sorguladığ1 1926 yılı tarihli Sinemanın Temel İlkeleri'ni yayınlar. Bu yapıtta, filmsel malzemenin, "üzerine çeşitli görüß̧ noktalarını, olgunun ayr ayrı hareketlerinin saptandığ bu selüloit parçaları" ndan başka bir şey olmadığını belirtir. Film yönetmeninin "gerçek uzay ve gerçek zamanda meydana gelen gerçek süreçler değil, fakat bu süreçlerin üzerine kaydedildiği bu selüloit parçaları" olarak üzerinde çalıştığ1 filmsel gerçeklikte, gerçekliği, isterse "zaman içindeki olguyu gereken en yüksek derecede" yoğunlaştırabileceğini söyler (Pudovkin, 1966: 8687).

Öte yandan, Arheim'ın karşı çıktığ1 “İlk kez dünyanın bir görüntüsü, insanın yaratıcı müdahalesi olmaksızın, otomatik olarak biçimlendiriliyor" (Aktaran, Kolker: 2010: 44) fikrini 1945 yılında tekrar savunan Bazin ve Yeni Gerçekçiler sinema ile gerçekliğin ilişkisini çok farklı biçimde ele alırlar:

"Bu görüş̧ çoğu fotoğraf̧̧ı ve yönetmen tarafindan küçümsenecekti. Ama kuramsal etkisi çok büyüktü. Hem Bazin hem de Yeni-Gerçekçiler dünyayla ilişki kuran ve bizleri bu dünyaya müdahale etmeksizin bu dünya ile ilişkilendiren bir araç olarak sinemasal araç arayışındaydılar. De Sica "gerçeklik orada, onu neden değiştirelim?" dedi. Yeni-Gerçekçiler sinemasal imgenin, eğer yönetmen yalnizca bakar ve mümkün olduğunca az müdahale edip düşüncelerini kendine saklarsa, yönetmenin gördüğü dünyayı açı̆̆a vuracağına inandılar" (Kolker, 2010: 44).

Bazin, "Tüm Sinema Miti” başlıklı yazısında, yönetmenleri, "imgelere inanan yönetmenler" ve "gerçeğe inanan yönetmenler" olarak ikiye ayırır ve "uygarlık tarihinin yüzyıllardır gerçekliğin arayışı içinde oluşunun, bunun elde edilmesi, kaydedilmesi ve istendiğinde yeniden kullanılabilmesi düşüncesi doğrultusunda sinemayı yarattığını vurgular. Buradaki gerçek, bir süre sonra, başka çalışmalar kapsamında, "yaratılan sinemasal gerçeklik" $i$ işaret etmeye başlayacaktır" (Kabaday1, 2015: 94). 
Bu yazıda, Bazin'in, fotografik görüntüye, dolaylı olarak da sinemaya dair söylediği "her ne kadar sonuç onun kişiliğini yansıtıyor olsa da, bu, ressamın yaptığı ile aynı şey değildir" (Bazin, 2011: 18) görüşüne karşı çıkılmaktadır. Sinemanın sinematik duyumsamayı oluştururken kullandığı kendine özgü araçları olan hareket, zaman, ritim, 1şık, gölge, doku, renk ve sesi düzenleme, seçilen görüş alanı, kamera ve kameranın optik devinimleri ile gerek nesnel, gerek öznel kamera kullanımı, alan derinliği açı karşı açılarla, genel plan yakın plan geçişleriyle bir uzamı kurarak ve kurgu aracılığıyla (Gök, 2007: 118) yaratmasının yönetmeni bir ressam kadar özgür kıldığı görüşü benimsenmektedir.

Sinema, dolayısıyla sanatın gerçekle ilişkisi konusunda son sözü, Andrei Rublev filmini inceleyeceğimiz sanatın öznelliğini vurgulayan ve sinemayı "filmsel sanat yapıtı" olarak gören Tarkovski'ye birakıyoruz:

"Filmsel sanat yapıtlarının amacı, izlenimlerinde gerçekliğin yalnızca bir yanılsaması, bir görüntüsü ortaya çıssa da sanatçının bir deneyim bütününü yeniden düzenlenmesini sağlamaktır. (...) Bir film görüntüsünün gerçekliği görünüşte gerçekliktir. Uygulamaya geçirme aşamasında yönetmen tarafindan seçilmiş, yani yönetmenin konumunun bireyselliğinden doğmuş özellikleri gözler önüne seren bir düşten, bir arzudan başka bir şey değildir. Kendi gerçeğine ulaşmaya çalışmak (zaten başka 'genel' bir gerçek de olamaz) demek, özgün fikirlerini şekillendirmek için özgün bir dil aramak demektir" (Tarkovski, 2008: 73).

\section{Sanatçı ve Sanat Eseri}

Tarkovski'nin yaratım sürecinin öznelliğiyle kurduğu ilişkiye uygun olarak, üç film, yaratıcısıyla kurduğu ilişki üzerinden ele alınacaktır. Çünkü sanat yapıtı, yaratıcısından yani sanatçıdan bağımsız değildir. Üç filmin ortak noktalarından biri, belirtildiği gibi, sanatçıyı merkezine almalarıdır. Ama bir yanıyla da üç film de kendi yaratıcısından yani yönetmenlerinden izler taşır. S. Moissej Kagan'a göre,

"Her şiir sanatının altında lirik bir kahraman vardır ve hiç kuşkusuz, bu kahraman da şairin kendi bir suretidir (...) sanatçının kişiliğinin bu iki varlık biçimi arasındaki başkalaşım, çok ya da az olabileceği gibi, (Goethe' de görüldüğ̈̈ üzere) derin, çatışma dolu çelişmelerden (örneğin, Brecht' te görüldü̈̆̈̈ üzere), hemen hemen tam bir uyuşmaya kadar uzanabilir" (Kagan, 1982: 344).

$\mathrm{Bu}$ anlamda, ele alınan üç yönetmen, Federico Fellini, Andrei Tarkovski ve Charlie Kaufman'da bu uyuşmanın, neredeyse tam bir özdeşliğe yaklaştığı söylenebilir. "Kişilik olarak sanatçının nitelikleri, sanatçının yaratı fa faliyetinin temel anı" olduğu fikrinden hareketle, sanatsal yöntemin, sanatçının dünya görüşü, estetik kanıları, sanatın özü ve belirlenişi üstüne kendi anlayışı, belirli bir toplumsal çevre içinde oluştuğu ve onunla belirlendiği söylenebilir (Kagan, 1982: 342). Bu sebeple, sanatçıların kişiliklerinin Arnheim'in belirlediği teknik olanakları biçimlendiren sanatsal yöntemini, yani sinemasal teknik tercihlerini belirleyen görüşlerine bakılacaktır.

Üç yönetmen de farklı tarihsel, toplumsal, kültürel bir arka plana sahiptir. Fellini ve Tarkovski'de iki büyük Hristiyan geleneğinin yoğun etkisi vardır. Fellini'nin filmlerinde kişiselliğin bütün görkemine karşın toplumsalın da izdüşümünden söz edilebilir. Onun filmleri bir yanıyla en uç sınırda kişisel, diğer yanıla ise kolektif bilinçaltının yansımalarıdır. Tarkovski de benzer biçimde, bireyci görünen filmlerinin arkasında Rus kültürüne dair bir 
görü ve anlayışı barındırır. Hatta Ulus Baker'e göre onun filmlerinde, “dikkat edilirse her imaj, her plan dönen ve sürekli olarak "Rusya Nedir... Rusya Nedir?" sorusunu soran bir kristale benzer" (Baker, 2011: 106). ABD'de yaşayan Kaufman ise aslen Protestan ağırlıklı bir ülke olsa da çok kültürlü ve günümüzün, 21. yüzyılın her anlamda ifadesini bulduğu bir yer olan filmin de çekildiği New York'a ait materyalist değerleri taşır. Ateist bir yönetmen olan Kaufman'ın filmleri ölüm kaygısının en yoğun hissedildiği filmlerdir. Buna uygun olarak Kaufman'da sanat Varoluşçu bir kaygının, insanın hayattaki varlığına, ölümle yüzleşmesine dair düşüncelerin bir görünümüdür. Fellini ve Tarkovski ise sanatı ve sanatçıyı daha üst bir konumda görür.

Fellini, cüretkâr bir yorumla sinemayı bir tür Tanrıyla yarışma yolu olarak tanımlar (Grazzini, 2006: 74). Onun için sanatçı olarak kendisinin benliği "bir demiurgos, evreni yaratan tanrı, olma hırsı" ile doludur (Grazzini, 2006: 74). Tarkovski ise sanatçıyı, Puşkin'in tanımından yola çıkarak bir peygamber yeteneğiyle donanmış olarak görür ve her sanatçının, diğer sanatçılar için bağlayıcı olmayan, kendine özgü yasalarla tanımlandı̆̆ını söyler (Tarkovski, 2008: 27). Ama onun için sanat daha metafizik bir yerde durur ve daha ilahi bir anlamla kurulur: "Sanat yaratma kapasitesidir. Yaratıcınn aynadaki yansısıdır. Biz sanatçılar bu jesti tekrarlamaktan, taklit etmekten başka bir şey yapmıyoruz. Sanat, yaradana benzediğimiz belirli bir andır" (Cosse: 2010). Bir anlamda Tarkovski'nin sineması, insanın doğanın estetik duyumsanması yoluyla kendi içinde aşkınsal olanı görme ve 'yüce' yle yüz yüze gelme anlamında Kant'ın estetik teorisinin sinemasal bir uygulaması gibidir.

Fellini için sinema anılarla, düşsellikle, hayal gücüyle ilişkilidir. Fellini, sürrealist bir yönetmen olmasa da, Birinci Sürrealist manifestoda Andre Breton tarafından açıklanan düşlerin yasalarıyla gerçeğin evrenini birleştirmeyi amaçlayan ${ }^{3}$ bir yerdedir adeta:

"Bizim çabamızın esası, rüya ile hayal gücü arasindaki sının yok etmek, her şeyi icad etmek ve bu fantastik işlemi daha sonra dışa vurmak, onu keşfedebilmek için hem dokunulmaz hem de tanınmayacak kadar çok değişmiş bir şey gibi onu bizden uzaklaştırmaktır" (Grazzini, 2006: 126).

Fellini, yaşlandıkça gerçekle olan bağını rasyonalize etmeye ihtiyaç duymadığını ifade eder (Grazzini, 2006: 5) ve gerçek yaşamla ilgilenmediği özellikle vurgular: "Gerçek yaşam beni ilgilendirmiyor. Gözlemlemeyi severim, ama bunu yalnızca düşgücümü özgür bırakmak için yaparım. Çocukluğumdan beri insanlar gördü̈̆̈̈̈m gibi değil, belleğimde yer ettikleri biçimle çizdim" (Chandler, 1995: 26). Fellini için tek gerçeklik düşlerdir (Chandler, 1995: 35).

Sanata daha maneviyatçı bir bakışla yaklaşan Tarkovski ise "film belge olduğu zamanın dışında bir düştür" diyen Bergman'a göre düşsel mekânlarda bir uyurgezerin güveniyle hareket edip bir açıklamaya bile ihtiyaç duymamasıyla yönetmenlerin en büyüğü itibarını hak eder (Bergman, 1990: 83). Sanatın görevinin maneviyatın diriltilmesi olduğunu söyleyen Tarkovski (Tarkovski, 2009: xv) ise sanat eseriyle karşılaşma adeta bir temizlenme, arınmadır.

\footnotetext{
3 Anre Breton’a göre, Sürrealizm sözcüğü yerine Süpernatüralizm sözcüğü de kullanılabilir. Çünkü sürrealizmin aslında Freud'un ortaya koyduğu psikanalitik araştırmaların vardığı rüyalar gerçeğin bir parçası olduğu sonucundan hareketle rüyalar ile gerçeği birleştirmeyi amaçlar (Breton: 2009).
} 
21. yüzyılın yaygın kaygılarını taşıyan Kaufman ise çok daha karamsardır. Kaufman'ın filmografisini en çok belirleyen görüş kuşkusuz Varoluşçuluk'tur. Synecdoche, New York'ta sürekli olarak hissedilen "bulantı" kavramı, Sartre' 1 n Bulantı isimli aynı isimli romanında: "nesne korkusu, fazladanlık, ölüm, varoluşun anlamsızh̆̆̆ı, saçmanın mutlak varlığı, insanın yalnızlığı gibi temalar üzerinde durarak anlatmıştır" (Güvenç, 2013: 55). Kaufman'ın filmlerinin anahtar kelimesi olan bu sözcükleri birleştiren bulantı kavramına daha yakından bakılırsa, "varoluşsal gerçekler karşısında duyulan şaşkınlık, nefret ve tiksinti duygularının genel adı" (Güvenç, 2013: 62) olarak tanımlanabilir. Kaufman'ın filmlerindeki temel varoluşçu sorun ölümün kaçınılmazlığı karşısında duyulan varoluşçu kaygıdır: "İnsanlar doğarlar, ölürler. Hayat süredurur. Evrende fiziksel varlığının esamisi okunmayan insan çabalar durur, yaşama tutunur. Sonra ansızın ölüm gelir, ya da doğal bir afet, belki bir hastalı... Insan anlar ki; hiçbir şey aslında kendisinin kontrolünde değildir"4 (Güvenç, 2013: 62). Öte yandan Kaufman'ın karakterleri bunu anlamlandırmakta güçlük çekip saçma ile boğuşurlar.

Senaryosunu yazdığ1 ya da yönettiği bütün filmlerinde gerçek ve kurgusal dünyalar arasındaki ilişkiyi filmin bir şekilde içine sızdıran Kaufman röportajlarında, sinemayla kurduğu kişisel ilişkiden bahsederken Amerikan sinemasının insanlarda gerçek-dışı beklentiler yarattığı için insanlara gerçekten zarar verdiğini düşündüğünü söyler. Kendi sinemasında ise tıpkı Caden'in Synecdoche, New York'taki hedefi gibi dürüst olmayı amaçlar. Sonuç ise bir anlamda ironiktir: Dürüst olmak, gerçeğe yaklaşmak için gerçekten uzaklaşmak. Kaufman'ın filmleri diğer iki yönetmenden çok daha sürreal yanlar barındırmalarıyla ayrılır. Bir anlamda Kaufman, sinemasal gerçeğe, nesnel gerçeğin reddi yoluyla ulaşılabileceğini iddia etmiş olur.

\section{4. "Otto e Mezzo", "Andrei Rublev" ve "Synecdoche, New York" Biçimsel Görünümler}

Sanatsal yöntemin yaratıcısının yönelimleriyle belirlendiği varsayımından hareketle yönetmenlerin görüşleri, ele aldığımız üç filmde de biçimsel olarak kolaylıkla belirlenebilir. Üç film kıyaslandığında ilk bakışta dikkati çeken özelliklerden biri, Otto e Mezzo'nun 1şıkla boyanmış yüksek kontrastlı planları, Andrei Rublev'in sonsuza uzanan genel planları ve gri tonlamalar1 ve Synecdoche, New York'un neredeyse monokrom denebilecek yeşil renk paleti olacaktır. Bu anlamda Synecdoche, New York özelinde ironik sayılabilecek bir durum vardır, üç filmin arasındaki tek renkli film olmasına rağmen genel karamsarlığı renklere de sinmiştir, adeta en renksiz filmdir.

Otto e Mezzo ise Fellini'nin ve modern sinemanın gelişiminde bir dönüm noktasında durur ve tek gerçekliğin düşler olduğunu düşünen Fellini'nin düşlerini izleyicisine sergiler. Andras Balint Kovacs'a göre, Otto e Mezzo'nun sinemanın gelişiminde bir dönüm noktası olmasının sebebi: “(...) yeni doğan modernizmin bütün önemli özelliklerini içeren ilk film olmasıdır. Her şeyden önce Fellini burada Yeni-Gerçekçi gelenekten tamamen kopar ve 'gerçekliğin' yalnızca yönetmenin fantezisinin bir nesnesi olarak yorumlanabileceği bir film yapar" (Kovâcs, 2010: 338).

${ }^{4}$ Synecdoche, New York'un girişinde küçük kızın söylediği şarkı: “Bir yer var, Olmayı çok isterim, Belirli bir kasaba (...) Buna Schenectady denir, Orada doğdum ve, Orada öleceğim, Benim ilk evim, Orada satın almayı umuyorum, Çocuk sahibi olmak, En azından orada denemek, Tatı Schenectady, Ve gömüldüğümde, Ve ben öldüm, Üzgün solucanlar, Kafamı yiyecek..." 
Fellini'nin en büyük duyarlılığ̣ 1şık kullanımında görünür. Onun teknik anlamda ışığa verdiği önem düşe yapılan vurguyla ilişkilidir:

"Işık, filmin özüdür. Ve bu yüzden -bunu sık sık söyledim- sinemada ışık ideolojidir, duygudur, renktir, tondur, derinliktir, havadır, öyküdür. Işık, fantastiğe, düşe eklenen, yok eden, sınırlayan, coşturan, zenginleştiren, nüanslandıran, altını çizen, benzeten şeydir, bu şeylere itibar kazandırır, kabul edilebilir hale getirir. Ya da tam tersine, gerçeği fantastik hale getirir, en gri günlük olayı mucizeye dönüştürür, şeffaflık katar, gerilimler, titreşimler önerir. (...) Film denen şey, ışıkla yazılır, form ı̧̧ıkla ortaya dökülür" (Grazzini, 2006: 113-114).

Fellini'nin düşselliği filmin biçimsel özelliklerinin bütününde hissedilebilir:

(Otto e Mezzo) "Modern film biçiminin ü̧̧ temel ilkesi çok özel bir karışım içinde sunuldu: üst düzeyde kişisel, hatta açıkça öz yaşamöyküsel öykü biçiminde öznellik; filmin film-yapımının kullanımı ve güçleri ve Fellini'nin film-yapımıyla filmin kendi yapılışına doğrudan göndermeleri de içeren belirsiz ilişkisi anlamında eleştirel kendini yansıtma. Sahnelerin çok gevşek bir zamandiziniyle, eğer varsa, çok zayıf nedensel düzenle ilişkili olduğu ve gerçekliğe karşı fantezi derecesinin her zaman fark edilebilir olmadığı öykünün tamamen 'zihinsel temelli' olması anlamında soyutlama. Bu nedenle 8 1/2 modern sinemanın ne olduğunu gösteren ilk açı örnek oldu" (Kovâcs, 2010: 340).

Özellikle Zerkalo (Ayna, Andrei Tarkovski, 1975) filminde Otto e Mezzo'nun etkisinde kalan ve anılarla şimdiyi, düşler ile gerçeği bir araya getiren Tarkovski'nin Andrei Rublev'inde ise biçimsel anlamda iki temel özellik göze çarpar: Genel planlardaki sonsuz alan derinliği ve doğanın alımlanışına karşı hassasiyet. Bu iki özellik de üstteki bölümde açıklanan Tarkovski'nin maneviyatçı düşünceleri ile uyumludur. Tarkovski'nin sonsuzluk ve sınırsızlık arayışına geçmeden önce, gerçeği sinemada yeniden üretebilmek konusundaki çelişkisini göstermek umuduyla doğaya karşı yaklaşımından bahsetmek istiyoruz. Üstteki bölümlerde adeta Kant'çı bir doğa tasavvuru içinde olduğunu belirtilen Tarkovski için ilahi bir bakışla gördüğü doğa filmsel görüntüde olabilecek en güzel sonucu verir (Tarkovski, 2008: 9). Ona göre hayattan uzaklaşmamak için filmleri sonradan renklendirmek bile tercih edilmemelidir (Tarkovski, 2012: 120). Oysa Tarkovski, olabildiğince gerçeğe yaklaşmaya dair bir arayış sonucunda, gerçeği çarpıtma noktasına varır: Andrei Rublev'in özellikle giriş sahnelerinde, geniş açı lensten kaynaklanan fıçılama etkisini fark etmemek imkânsızdır. Üç keşişin yağmurdan derme çatma kulübeye sığındığı sahnede ve delinin performansı sırasında bu en üst seviyesine ulaşır. Bu görüntü, had safhada stilistiktir, hayata yakın olması söz konusu değildir.

Ama Tarkovski'nin en öne çıkan biçimsel özelliği kuşkusuz Tanrısal bir bakış arayışının eşlik ettiği genel planlar ve alan derinliğinin kullanımıdır. Andrei Rublev'de, sahneler boyunca. Ön planda karakterler görünürken Pieter Bruegel the Elder'den alınan bir perspektifle, arkada hareket devam eder. Tarkovski, sinemasında bütün dünyayı görmek ve anlamak ister. Onun arayışı sonsuza ulaşmaktır (Tarkovski, 2008: 28). Bu sonsuzluk deneyimi ise yalnızca sanat yoluyla yaşanabilir (Tarkovski, 2008: 29).

Kısaca Tarkovski, Andrei Rublev'de insanın içindeki maneviyatı kışkırtmaya yönelik bir sonsuzluk duygusu oluşturacak alan derinliği, perspektif, geniş açılar ve mekânlar 
kullanır. Filmlerinin ayrılmaz motifi olan doğa, insanın içindeki yüksek ahlakı uyandırmayı hedefleyen aşkınsal ve sonsuz doğadır.

Bu noktada, Kaufman, Synecdoche, New York'ta tem tersi bir yaklaşım ortaya koyar. Bütün sahneler, New York gibi bir şehirde geçer ve doğanın gözüktüğü planların sayısı yok denecek kadar azdır. Mekânlar yapay, evren kapalı ve sıkışıktır. Tarkovski'nin Tanrısal sonsuzluğuna karşıt buradan sınırsız sıkışmışlık vardır. Hatta filmin sonunda bu o kadar aşırıya varır ki, New York'un bir simülasyonu haline gelen tiyatro sahnesinin çatısı bütün gökyüzünü kaplar ve şehri tamamen sinırlar. Synecdoche, New York'u yine Varoluşçuluk üzerinden açıklamaya devam esilirse: En net ifadesini Sartre'ın felsefesinde bulan Varoluşçuluk, "her şeyden önce dünyada kendimizi var olurken bulmamız ve ardından yaşamımızla ilgili ne yapacağımıza karar vermek zorunda olmamız düşüncesinden gelmektedir" (Warburton, 2015: 292). Filmdeki Caden'in sıkışmışlığı ya da varoluşçu anlamda "iç daralması" denebilecek his de işte bu ne yapacağına karar verememe yani Caden'in "kendini hiçlik yani özgürlük olarak yaratan kendine özgü varlı̆̆ının bilincine varması"ndan kaynaklanır (Bochenski, 1997: 209). Kendisine ölçüsüz bir maddi özgürlük tanıyan ödülden sonra Caden, özgürlüğünün bilincine varır ama bu bütün eylemlerinden sorumlu olmayı da getirir ki bununla baş edemeyen Caden zamanla yıkılır: "İnsan iç daralmasından kaçmakta ve bunu yaparken de yalnızca özgürlüğ̈̈̈nden, yani geleceğinden değil, aynı zamanda geçmişinden de kaçmaya çabalamaktadır" (Bochenski, 1997: 209).

Mekânlardaki bu sınırlılık ve sıkışmışlık beraber, Synecdoche, New York'un girişinden itibaren bir melankoli hissinin eşlik ettiği bulantı, neredeyse monokrom yeşil renk ile belli olur ve ölüm düşüncesi film boyunca görünen çürüyen, bozulan, yıkılan, yıllanan şeyler ile görünür kılınır.

Yönetmenlerin görüşlerine göre belirlenen estetik stiller, Fellini'de daha kayıtsız bir sirk havası, Tarkovski' de çileci bir iman ve maneviyat, Kaufman'da ise aşılamaz bir kaygı şeklinde görünür. Ama daha önemli bir nokta bu stillerin filmlerdeki krizle bağlantısıdır.

\section{Etik Estetik Kriz}

Girişte de açıklandığı gibi üç filmin ortak noktası bir sanat eseri ortaya koymak isteyen ama yaratıcı eyleme geçmede kriz yaşayan sanatçıdır. Ama önemli olan nokta, krizin çıkış noktasıdır: Dürüst bir sanat eseri koyma isteği. Hepsi de aynı şeyle karşı karşıya kalırlar: "Gerçeği imleyememe hali". Bu fikri en uca götüren Synecdoche, New York olur ama Andrev Rublev ve Otto e Mezzo' da da sanatçı karakteri benzer sorunlarla boğuşurlar.

Otto e Mezzo'nun ana karakteri yönetmen Guido'nun, Fellini'nin bir tür personası olduğu kabul edilen bir gerçektir. Fellini film yapım sürecini açıklarken, bir film yapma isteğiyle yola çıktığını ama yapım süreci sırasında kendisine ilham veren fikri tamamen unuttuğunu ve artık ne yapmak istediğini bilmediği için filmi bırakma aşamasına geldiğini söyler. $\mathrm{O}$ an aklına yeni bir fikir gelir, tam olarak içinde bulunduğu durumu çekecektir: Bir film çekmek isteyen ama ne çekmek istediğini bilmeyen bir yönetmen (Grazzini, 2006: 114115). Filmdeki yönetmen Guido, filmin farklı sahnelerinde yalan söylemek istemediğini, 
dürüst bir film yapmak istediğini dile getirir ${ }^{5}$ ama filmdeki karısı Luisa tarafından sıklıkla belirtildiği gibi o bir yalancıdan başka biri değildir. Fellini bunu özellikle vurgulamak için bir sahnede Guido'ya doğrudan takma bir Pinokyo burnu giydirir. Yaratma krizindeki Guido, esin perisi Claudia'yı görmeden önce kendi kendine konuşur ve yalancının biri olduğunu itiraf eder6. Sanat eserini ortaya koymak için dürüst olmak imkânsızdır. Filmin deneme çekimlerini izledikleri sahnede Luisa, Guido'yu filmi çekerken kendi gerçeklerini çarpıtmakla, her şeyi görmek istediği biçimde yansıtmakla suçlar ve "hadi kendi filmini yap" der ${ }^{7}$. Ki Guido yapamasa da Fellini tam olarak bunu yapar, kendi filmini, kendi gerçekliğini yaratir.

Sanatta, gerçeği olduğu gibi aktarmak mümkün değildir, Wilde "Şayet insan bir hikâyeyi aşırı gerçek kılarsa, onun gerçekliğini öldürmüş olur" (Wilde, 2008: 168) der, Fellini için ise "Gerçeğe ne kadar taklitçi yaklaşılırsa, taklit o kadar zorlaşır" (Grazzini, 2006: 112).

Fellini gerçek hayatında da yalancı tanımıyla karşı karşıya kalmıştır ama onun için sanatçı zaten gerçek ile ilgilenemez:

"Bizim yalancı olduğumuzu söylüyorlar. Ama bu doğru değil. Bu böyle işte, görünürdeki gerçek bizi ilgilendirmiyor. Ama aslında hangi gerçek gerçekten gerçek? Bize dışarıdan, başkaları tarafindan dayatılan mı? Bu daha çok, düşgücümüzün sahnesinde oynayan şu sonsuz hikâye değil mi? Asıl gerçek kafalarımızın içinde ve sanatçı olarak ifade etmemiz gereken de o" (Chandler, 1995: 378).

Fellini için, ressamın gördüğü gerçek, kişisel bir gerçekliği gösterir ve bu kişisel gerçek, en fazla gerçekliği içermesi dolayısıyla onun için mutlak gerçektir (Chandler, 1995: 116).

Andrei Rublev de benzer bir sorunu ele alır. Ama Andrei Rublev'deki "gerçek" Tarkovski' nin görüşlerine uygun olarak daha çok ilahi bir hakikatin arayışı gibidir. Andrei Rublev filmde ikonları için ahlaki bir destek arar, saf olan, iyi ve doğru olana, tanrısal olana dair bir şey yapmak ister ama hayat acı içindedir:

(Andrei Rublev) "Dünyada şiddetten, ihanetten, alçakliktan ve kıskançlıktan başka bir şey bulamadı̆̆ın anladığında tereddüt eder ve korkar. İnsanın eğer 'ilahi bir yüzü' yoksa ilahi sanatı hak etmediğgi sonucuna varır. Ve Rublev insanları kendi yoz doğaların yansıtan resimleriyle korkutmak istemediği için, dünyayla bütün ilişkilerini keser. Yalnızca resim yapmayı bırakmaz, aynı zamanda sessizlik yemini de eder" (Kovâcs, 2010: 361).

Andrei Rublev, filmde sessizlik yemini etmeden önce, ölmüş ustası Yunanlı Theophanes'in hayalini görür ve bir zamanlar inandığı yüksek ülküyü artık bıraktığını söyler, ustasının bir zamanlar dile getirdiği duyarsız görüşlerin artık gerçek olduğunu kabul eder8. Ama Yunanlı

\footnotetext{
${ }^{5}$ Guido: “Düşüncelerimin çok açık olduğunu düşünmüştüm. Dürüst bir film yapmak istedim. Hiç yalan olmayacaktı. Söyleyecek çok yalın şeylerimin olduğunu düşünmüştüm. Herkese yararlı olacak bir şeyler. lç̧imizde taşıdığımız bütün ölmüş şeyleri ebediyen gömmeye yarayacak bir film. Benimse bir şeyleri gömecek cesaretim hiç yok. (...) Ne zaman yanlış yaptım? Gerçekten bir şey söyleyemiyorum... Ama yine de söylemek istiyorum..."

${ }^{6}$ Guido: "Esin perileri gelmiyor, ha? Bir tanesi bile geçmiyorsa yani ne olmuş küçük bey? Ne olmuş yani yıkılışısa özel bir becerisi olmayan iğrenç bir yalancının?"

7 Guido: "Sadece bir film". Luisa: "Ben de biliyorum film olduğunu. Bir film, başka bir buluş, başka bir yalan. İ̧ine her şeyi görmek istediğin biçimde koymuşsun. Ama gerçek bambaşka. (...) Haydi yap. Kendi filmini yap".

${ }^{8}$ Andrei Rublev: "Hayatımın yarısını kör olarak geçirdim! Yarııını, bu şekilde... Insanlar için gece gündüz demeden çalıştım. Ama onlar insan değillerdi. Öyleyse söylediklerin gerçekti. Gerçek."
} 
Theophanes, tam tersini söyleyerek karşılık verir, ikisi de yanılmıştır9 ${ }^{9}$ Filmin sonundaki muhteşem çan yapımı sahnesinin ortaya koyduğu düşünce, Tarkovski'nin Puşkin'in sanatçının peygamber yeteneğiyle donanmış olduğunu aktarmasına uygun olarak, sanatın bir vahiy olarak içsel bir özden geldiğidir. Andrei Rublev uzun yıllar sessizlik yeminini tuttuktan sonra grandük için büyük bir çan yapmayı üstlenmiş, ölmüş bir çan dökümcüsünün oğlu Boriska karşılaşır. Genç Boriska ne yaptığını biliyor gibidir ama çan yapımı tamamlandığında Andrei'ye aslında çan yapmanın sırrını bilmediğini itiraf eder. Tıpkı çanın üstündeki Aziz George'un imanın gücünü vurgulaması gibi, Boriska, çanı bir bilgiyle değil içsel bir esinle yapmıştır. Sanatın gerçeğin desteğine ihtiyacı yoktur:

"Andrei sessizlik yeminini bozar ve resim yapmaya yeniden başlamaya söz verir. Sanatçının dış dünyadan bir şey beklememesi gerektiğini anlar. Sanatı destekleyecek hiçbir şey yoktur. Sanatçının güvenebileceği tek şey içsel tinsel esindir. (...) Sanatın sırrı gerçeklï̆in nasıl sanat içinde dönüştürülebileceği değil, ama sanatın arkasındaki gerçekliğin sağlam desteği olmaksızın ortaya çıkmasının nasıl mümkün olduğudur. (...) modern sanat yapıtında gerçeklik sanatçının kendi zihinsel ya da ideolojik yaratımından başka bir şey değildir. Bunun arkasında başka bir gerçeklik yoktur" (Kovâcs, 2010: 362).

Bu düşünce filmin tarihi yorumlama şeklinde de görünür. Wilde, Orta Çağ'ın sadece bir stilden ibaret olduğunu söyler (Wilde, 2008: 196), Tarkovski ise sinemanın "pratikte kendisinin gücünü sınırlandırmaktan öteye geçemeyen hiçbir tarih anlayışına ihtiyaç" duymadığını, "Andrev Rublev'i yaparken de asla tarihsel bir film yapma peşinde" olmadığını söyler (Ahmedi, 2016: 27). Hatta Orta Çağ'da yaşayan birinin filmi izleyecek olsa garipseyeceğini çünkü tarihsel verilere bağlı kalmamayı tercih ettiklerini ifade eder (Tarkovski, 2008: 64). Wilde'ın "İyi sanat, herhangi bir çağın simgesi değildir, içinde üretildiği çă̆ onun simgesidir asıl" (Wilde, 2008: 195) görüşüne benzer biçimde Tarkovski için: "Yaşadığımız dönem ile hiçbir ilişkisi olmayan tarihsel filmleri anlamıyorum. Bana göre en önemli şey, tarihi kaynaklardan yararlanarak modern insanın inanç ve düşüncelerine açıklık getirilip yaşadığımız dönemde 'yeni insan şahsiyeti' nin yaratılmasıdır" (Ahmedi, 2016: 27). Ona göre Rublev'den kalan ikon'lar, Orta Çağ ile günümüz arasında bir bağ kurmaktadır (Tarkovski, 2008: 65). Andrev Rublev'in tarih anlayışı yayınlandığı dönemde de tartışma konusu olmuştur. Dönemin Sovyet Birliği eleştirmenleri, filmi, resmi tarihe karşı olmakla suçlarken ${ }^{10}$ aslında tam olarak Tarkovski'nin yapmaya çalıştığını şeyi anlamış olurlar. Wilde'ın dediği gibi: “(...) biz geçmiş çağlara sanat aracılığıyla bakanz ve sanat, neyse ki, bize hiçbir zaman gerçeği söylemez" (Wilde, 2008: 198).

Ama üç yönetmen arasında Wilde'ın radikalliğine en çok yaklaşan Kaufman ve Synecdoche, New York'tur. Kaufman, ilk filmlerinden itibaren kurgu ve gerçeğin iç içe geçmesinin farklı biçimde işlemiştir ama Synecdoche, New York'ta bu bambaşka bir boyuta ulaşır, filmsel gerçek, filmin içindeki kurgusal gerçeği taklit etmeye başlar ya da Wilde'ın ifadesiyle, filmin içindeki hayat, sanatı taklit etmektedir.

\footnotetext{
${ }^{9}$ Andrei Rublev'e yanıt veren Yunanlı Theophanes: "Benim ne söylediğim önemli değil. Şu an yanılıyorsun, o zaman da ben yanılıyordum."

10 Film sansüre uğramıştır, 1966 yılında çekilmesine rağmen, 1971'de gösterime girmiştir, 215 dakika yerine 185 ve 146 dakikalık kopyaları gösterilmiştir (Ahmedi, 2016: 305).
} 
Filmin girişinden itibaren sanat ve gerçeğin ilişkisinin irdeleneceğini bellidir, mimesis kavramını imgelercesine bir ayna görüntüsüyle başlar. Caden oldukça depresif halde yatağında uzanmış aynadaki görüntüsüne bakmaktadır. Radyodan sonbaharın ilk gününün başladığı bildirilir ve bir edebiyat profesörüyle sonbaharın ölümle bağlantısı üzerine söyleşi yapılır. Filmin daha girişinde profesörün okuduğu şiir, bir oyun yazarı ve sanatçı olarak Caden'in sanatsal arayışı ve arzusu da dile getirilir: Sert ama gerçek ${ }^{11}$. Hatta Kaufman'ın da filmi çekerken amacının bu olduğu söylenebilir. Ama gerçeklik mümkün müdür? Film boyunca Caden farklı sahnelerde gerçek ve dürüst bir eser koymak istediğini söyler ${ }^{12}$ ve kendisine sonsuz bir özgürlük sağlayan ödülü bu gerçekliğe ulaşmak için kullanmaya adar ${ }^{13}$. Yillar geçer ama Caden bu amacına asla ulaşamaz, o gerçeği oyununa yansitmak isterken, kendi hayatı tiyatro oyunun bir parçası haline gelir. Filmin sonunda Caden'in yerine geçen Elen' in verdiği direktifler artık gerçeği belirlemeye başlar, kurgusal olan gerçek olanın yerini alır. Elen'in Caden'a yönetmen olarak verdiği “Öl” direktifi sonrasında görüntü aydınlanır ve film biter. Bir anlamda Synecdoche, New York'un güncelliği ve gerçeğin sanat üzerine yaklaşımı, diğer iki filme benzese de Wilde'ın yaklaşımı bağlamında daha cesurdur. Aslında bu üç filmin de çekilmiş olmaları, yönetmenlerin gerçeği söyleyemeyeceklerini kabul ettiklerini gösterir. Gerçekçiliğin zindandan kurtulmak onları özgürleştirmiştir:

"Yalancıyı büyük bir mutlulukla karşılayan, halk olmayacak yalnızca. Sanatın kendisi de, gerçekçiliğin zindanından kaçıp kurtulacak, yalancıyı karşılamak üzere koşmaya başlayacak, hakikat dediğimiz şeyin bir stil meselesi olduğunun bilincinde olarak, onu güzel dudaklarından öpecektir" (Wilde, 2008: 183).

\section{Sonuç}

Otto e Mezzo ve Andrei Rublev'de sanatçı karakteri, gerçekle muhakemesinin sonucunda, sanatın içsel bir kaynağı olduğunu kabul eder ve bir anlamda gerçeğin hükümranlığından kurtularak özgürleşir. Wilde'ın dediği gibi, "Sanat, aradığı mükemmelliği, dışarıda değil, kendi içinde bulur" (Wilde, 2008: 184). Oysa Synecdoche, New York'ta sanatçı umutsuzca sanat eserinde gerçeği yeniden yaratmaya çalışır ve sanat eserini tamamlayamaz, en sonunda kendisi bu eserin bir parçası haline gelir. Her halükarda çıkan anlam, gerçekliğin yeniden üretiminin olanaksızlığının yarattığı etik krizi aşmanın tek yolu olarak, sanatın gerçeği doğrudan imleyemeceği, onu (gerçeği) çarpitmasa bile ancak sanatsal materyal (yani film) ile yeni bir gerçek yaratabileceğidir. Heidegger'in dediği gibi, sanatın gerçekliği sanat eserindedir.

\footnotetext{
${ }^{11}$ Radyo sunucusu: "Hemen konuya girelim. Neden birçok insan sonbahar mevsimi hakkında yazıyor?" Profesör: "Sanırım, genelde sonun başlangıcı olarak görüldüğ̈ için. Eğer hayat bir yıl olarak düşünülürse, o halde sonbaharın başlangıcı Ekim güllerin solduğu ve yaşayan şeylerin öldüğü zamana denk geliyor. Ekim bir melankoli ayı ve belki de onu güzel yapan da bu." R. S.: "Bize okumak isteyebileceğiniz bir şeyler var mı peki?" P: "Seve seve: 'Kimin ki şu anda evi yok, asla da olmayacak. Kim ki yalnız, yalnız kalacak. Okuyacak, oturacak, akşam çökünce uzun mektuplar yazacak Ve volta atacak yollarda, yorulmak bilmeden. Ve etrafında yaprak döken ağaçlar olacak'." R. S.: "Tanrı aşkına, bu biraz sertti değil mi?" P: "Belki de. Ama gerçek."

${ }^{12}$ Caden: "Çok yalnızım. Acı çekiyorum. Bence Adele haklı. Ben gerçek olan hiçbir şey yapmıyorum..." Psikolog: "Gerçekten kastın ne?" Caden: "Korkarım öleceğim."

13 Psikolog: "O parayla ne yapacağını biliyor musun?" Caden: "Tiyatroda kullanacağım. Büyük, doğru ve güçlü bir şeyler." Yeni tiyatronun ilk toplantısında, Caden: "Amaç çok güzel bir tiyatro oyunu sergilemek. Dik duran, dürüst. Işste sanırım tiyatro bu. Düşüncenin başlangıcı. Dile getirilmemiş bir gerçek."
} 
Sanat eserinin kaynağı, Wilde'ın savunduğu gibi, gerçek değil, sanatın kendisidir, sanat, eserde var olan hakikati ortaya çıkarır. "Sanat, kendinden başkasını ifade etmez; kendisi dışındaki hiçbir şeye ayna tutmaz. Benim önerdiğgim yeni estetiğin en başta gelen ilkesi de budur; bütün sanatlan her şeyin temeli, asal unsuru haline getiren de, (...) yine sanatın yalnızca kendini ifade ettiği gerçeğidir (Wilde, 2008: 194)".

Sanat eserini yaratırken ister yalan söylensin ister dürüst olmaya çalışılsın sonuçta gerçeği ifade yoluyla yeniden biçimlendirmeden yaratmak mümkün değildir. Arnheim'ın dediği gibi bütün bu biçimsel tercihlere rağmen eser "her şeye rağmen gerçeklikle çatışmayabilir" (Arnheim, 2002: 46) ama bu oluşturulan eserin gerçek ya da gerçekçi olduğu anlamına gelmez, sanatın ve bir sanat biçimi olarak sinemanın "kendine ait bir gerçekliği" vardır. Fellini de gerçeği çarpıtmadığını ama temsil ederken "düzenlediğini" söyler:

\footnotetext{
"Ben gerçeği çarpıttı̆̆ımı hiç sanmıyorum. İsterseniz, onu temsil ettiğimi söyleyelim. Ve gerçeği temsil ederken, ifadeden oluşan bir kategoriye başvuruyorum. İfade, öyküye, anlatıya ait olan dengeyi araştııırken tasfiye eder, seçer, ayııı ve yeniden düzenler. (...) O andan itibaren ifade her zaman için bir çarpıtma olarak yorumlanabilir, belki gerçekten de öyledir. Çünkü ifade, süzülmüş, gösteriminde yeniden düzenlenmiş gerçekliktir. Şiirde, en doğal resimde, müzikte gerçek çarpıtılmıştır. Bu hem sanattır hem de farksızlaştırılmıştan, kargaşadan çıartılan bir düzendir. Ve estetik duygusu olarak tanımlanan bir iç dinlemeyi içerir" (Grazzini, 2006: 135).
}

Fellini'nin de belirttiği gibi, sanat gerçeği çarpıtmayıp temsil etse bile gerçekliği her halükârda değiştirir, sanatın özü bunu gerektirir, estetik etik krizden kurtulmak ancak bunu kabullenmek ile mümkündür. Sanat eseri kendi gerçekliğini oluştururken dişsal gerçekten bağımsızdır ve bunu yaparken de kendi hakikatini yaratır.

\section{Kaynakça}

Adanır, O. (2008). Simülasyon Kuramı Üzerine Notlar ve Söyleşiler. İstanbul: Hayalet Et Kitap.

Ahmedî, B. (2016). Kayıp Umudun İzinde Andrey Tarkovski Sineması. (F. Soysal, \& V. Başç1, Çev.) İstanbul: Küre Yayınları.

Arnheim, R. (2002). Film'den Uyarlanmış Seçmeler. R. Arnheim içinde, Sanat Olarak Sinema (s. 14-138). Ankara: Öteki Yayınevi.

Avc1, İ. B. (2016). Jean-Paul Sartre' ın Varoluşçu Düşüncesinin İzlerini Modern Sinemada Aramak: Çölde Çay Filmi. İletişim Fakültesi Akademik Dergisi, 325.

Baker, U. (2011). Beyin Ekran. İstanbul: Birikim Yayınları.

Bazin, A. (2011). Sinema Nedir? (İ. Şener, Çev.) İstanbul: Doruk Yayımcılık.

Bergman, I. (1990). Büyülü Fener. (G. Taşkın, Çev.) İstanbul: Afa Yayınları.

Bochenski, J. M. (1997). Çă̆daş Avrupa Felsefesi. (S. R. Kırkoğluu, Çev.) İstanbul: Kabalcı Yayınevi. 
Bozkurt, N. (1995). Sanat ve Estetik Kuramları. İstanbul: Sarmal Yayınevi.

Breton, A. (2009). Sürrealist Manifestolar. (Y. S. Kafa, A. Günebakanl1, \& A. Güngör, Çev.) İstanbul.

Chandler, C. (1995). Ben, Fellini. İstanbul: Afa Yayınc1lık.

Cosse, L. (2010). Bir Sineastın Portresi: Tarkovski ile Filmleri Üzerine. (G. Güner, Düzenleyen, L. m. cinema, Prodüktör, \& France Culture) Aralık 17, 2017 tarihinde Avrupa Sineması: http://www.avrupasinemasi.com/2010/07/05/andrei-tarkovski-roportaji/ adresinden alınd 1

Gök, C. (2007). Sinema ve Gerçeklik. Sosyal Bilimler Dergisi, 112-123.

Grazzini, G. (2006). Federico Fellini. (C. Akalın, Çev.) İstanbul: Agora Kitaplığı.

Güvenç, E. (2013). J. P. Sartre Felsefesinde Bulantı Kavramı. Yayınlanmamış Yüksek Lisans Tezi. Bursa: Uludağ Üniversitesi Sosyal Bilimler Enstitüsü.

Heidegger, M. (2011). Sanat Eserinin Kökeni. (F. Tepebaşılı, Çev.) Ankara: De Ki Basım Yayım.

Kabadayı, L. (2015). Sinemada Felsefe ve Film-Felsefesi Üzerine. Doğu Batı Üç Aylık Düşünce Dergisi(Sinema Tutkusu I), 89-117.

Kagan, S. M. (1982). Güzellik Bilimi Olarak Estetik ve Sanat. (A. Çalışlar, Çev.) İstanbul: Altın Kitaplar Yayınevi.

Kolker, R. P. (2010). Değişen Bakış, Çağdaş Uluslararası Sinema. (E. Yılmaz, Çev.) Ankara: De Ki Basım Yayım.

Kovâcs, A. B. (2010). Modernizmi Seyretmek. (E. Yılmaz, Çev.) Ankara: De Ki Basım Yayım.

Pudovkin, V. I. (1966). Sinemanın Temel İlkeleri. (N. Özön, Çev.) Ankara: Ankara Üniversitesi Basımevi.

Schaper, E. (2005). Beğeni, Yücelik ve Deha: Doğa ve Sanat Estetiği. (A. Kaftan, Dü.) Cogito Dergi(41-42).

Tarkovski, A. (2008). Mühürlenmiş Zaman. (F. Ant, Çev.) Agora Kitaplığı.

Tarkovski, A. (2009). Şiirsel Sinema. (J. Gianvito, Dü., \& E. Kılıç, Çev.) İstanbul: Agora Kitaplığı.

Tarkovski, A. (2012). Film Yönetimi Dersleri. S. Aslanyürek içinde, Tarkovski'den Sinema Dersleri, Tarkovski'nin Hayatı ve Eserlerine Dair (s. 1-135). İstanbul: Agora Kitaplığ1.

Warburton, N. (2015). Felsefenin Kısa Tarihi. (G. Ateşoğlu, Çev.) İstanbul: Alfa Yayınları. 
Wilde, O. (2008). Yalanın Gözden Düşüşü: Bir Gözlem. O. Wilde içinde, Sanatçı: Eleştirmen, Yalancı, Katil, Estetik ve Etik Üzerine (E. Soğancılar, \& K. Genç, Çev., s. 161-205). İstanbul: İletişim Yayınları.

Wood, A. W. (2009). Kant. (A. Kovanlıkaya, Çev.) Ankara: Dost Kitabevi Yayınları. 